\section{A Versatile and High-yielding Protocol for the Preparation of Genomic DNA from Capsicum spp. (Pepper)}

\author{
J.P. Prince', Y. Zhang, E.R. Radwanski, and M.M. Kyle \\ Department of Plant Breeding and Biometry, Cornell University, Ithaca, \\ NY 14853
}

Additional index words. genomic DNA isolation

\begin{abstract}
The isolation of genomic DNA from Capsicum spp. (pepper) of the quality and quantity required for analyses based on nucleic acid hybridization and/or the polymerase chain reaction (PCR) has proven difficult. We report here a procedure that reliably yields sufficient quantities of good-quality pepper genomic DNA from a variety of Capsicum genotypes.
\end{abstract}

The isolation of genomic DNA from Capsicum spp. of a quality and quantity sufficient for molecular biological and plant breeding analyses based on hybridization technology and/or the polymerase chain reaction (PCR) (e.g., variety fingerprinting, gene mapping, and/or tagging) has proven difficult. In particular, studies of disease resistance can be handicapped by the lower yield of tissue, and, therefore, DNA from infected plants. Several procedures have been published, but none has proven widely adaptable. A nuclear lysis procedure that works well for tomato (Lycopersicon esculentum Mill.) leaves and fruit works only for pepper fruit (J.P. Prince, unpublished; Tanksley et al., 1988). Thus, the protocol requires a relatively long period before suitable tissue can be obtained and is limited to plants that set an adequate number of fruit. A procedure used in previous mapping studies yields small quantities of DNA of variable size and digestibility, but only from new, unexpanded leaves (J.P. Prince, unpublished; Prince et al., 1992). Finally, a rapid procedure using glass beads and a paint shaker that successfully was used to isolate DNA from dehydrated tomato and rice (Oryza sativa L.) leaves (Tai and Tanksley, 1990) failed to yield any DNA from pepper (J.P. Prince, unpublished).

We have adapted a procedure for the isolation of DNA from rice (McCouch et al., 1988) that reliably yields good quality pepper genomic DNA from leaves and fruits. The regu-

\footnotetext{
Received for publication 21 June 1996. Accepted for publication 13 Jan. 1997. Acknowledgment is made for support in part by the USDA NRI Award no. 94-37300-0333, The California Pepper Commission/California Pepper Improvement Foundation, U.S.-Israel BARD Award no. IS-2389-94, Asgrow Seed, DNA Plant Technology, and Sakata America. We thank M.A. Mutschler and J. Zhao for critical review of the manuscript and V. Lackney, G. Moriarty, and J. Jantz for technical assistance. The cost of publishing this paper was defrayed in part by the payment of page charges. Under postal regulations, this paper therefore must be hereby marked advertisement solely to indicate this fact.

${ }^{1}$ Current address: Dept. of Biology, California State Univ., Fresno, CA 93740
}

lardemand for this unpublished protocol stimulated this publication. The current version of the protocol has produced DNA of excellent quality and high yield (on average, $1 \mathrm{mg}$ from $7 \mathrm{~g}$ of fresh pepper leaves) from a variety of Capsicum genotypes, viz., $C$. апnuum L. 'NuMex R Naky', 'Jupiter', and 'Perennial'; C. chinense Jacq. PI 159234 and PI 159236; C. frutescens L. BG2814-6; and C. baccatum $\mathrm{L}$. PI 439364, PI 441563 'Pendulum', and PI 497985.

\section{Materials and Methods}

Whole pepper leaves were harvested into small manila envelopes on ice or in liquid $\mathrm{N}$ and stored at $-80^{\circ} \mathrm{C}$ until required. Because yield from older leaves is lower, leaves from seedlings or the youngest leaves on a mature plant are the most desirable. Importantly, although the DNA from older leaves is often yellow or brown, digestion by restriction endonucleases is successful. The frozen pepper leaf tissue was ground to a fine powder (light green) with mortar and pestle well chilled with liquid N. A chilled paintbrush was used to aliquot the frozen powder into prelabeled 50$\mathrm{mL}$ polypropylene tubes (with caps) chilled in liquid $\mathrm{N}$. Each tube contained $\approx 15 \mathrm{~mL}$ of frozen powder. Care was taken to keep the powder frozen (it turns dark green upon thawing). The tubes of ground tissue were stored at $-80^{\circ} \mathrm{C}$.

One liter of urea extraction buffer contained $420 \mathrm{~g}$ urea, $70 \mathrm{~mL} 5 \mathrm{M} \mathrm{NaCl}, 50 \mathrm{~mL} 1 \mathrm{M}$ Tris. HCl pH 8.0, $80 \mathrm{~mL} \mathrm{0.25} \mathrm{м} \mathrm{EDTA} \mathrm{pH} \mathrm{8.0,}$ $50 \mathrm{~mL} \mathrm{5 \%}$ Sarkosyl (Sigma, St. Louis), $50 \mathrm{~mL}$ phenol (equilibrated with Tris buffer) and $2 \mathrm{~g}$ sodium bisulfite. The final concentrations were $7 \mathrm{M}$ urea, $0.35 \mathrm{M} \mathrm{NaCl}, 0.05 \mathrm{M}$ Tris $\cdot \mathrm{HCl}, 0.02$ м EDTA, $0.25 \%$ Sarkosyl, $5 \%$ phenol, and $0.2 \%$ sodium bisulfite $(\mathrm{w} / \mathrm{v})$. The urea was dissolved in $300 \mathrm{~mL}$ distilled $\mathrm{H}_{2} \mathrm{O}$ by heating to $65^{\circ} \mathrm{C}$ and stirring. When the buffer was to be used immediately, the other components were added in the order given above, along with sodium bisulfite at $2 \mathrm{~g} \cdot \mathrm{L}^{-1}$, and the final volume was adjusted to $1 \mathrm{~L}$ with distilled $\mathrm{H}_{2} \mathrm{O}$. Sodium bisulfite at $1 \mathrm{~g} \cdot \mathrm{L}^{-1}$ was added if the buffer had been heated previously. This buffer may be stored at $4{ }^{\circ} \mathrm{C}$ with the container wrapped in aluminum foil. If the buffer was to be stored before use, the phenol and sodium bisulfite were omitted and added immediately before use.

Sixteen samples were easily extracted at one time. Tubes containing frozen leaf powder were removed from the $-80{ }^{\circ} \mathrm{C}$ freezer and kept in liquid $\mathrm{N}$ until the extraction. Hot $(65$ $\left.{ }^{\circ} \mathrm{C}\right)$ extraction buffer $(25 \mathrm{~mL})$ was added to each tube of frozen powdered tissue, while the melting powder was stirred with a metal spatula. Next, $0.75 \mathrm{~mL} 20 \%$ sodium dodecyl sulphate (SDS) was added to each tube. The capped tubes were inverted several times to mix the contents. The tubes were incubated at $65^{\circ} \mathrm{C}$ for $30 \mathrm{~min}$, with inversion to mix the contents every 10 min.

Chloroform : isoamyl alcohol (24:1) was added to fill the tube to the top. The tubes were tightly capped and mixed well by inversion. The rack of tubes was placed on its side on a rotary shaker and shaken gently ( $\approx 90 \mathrm{rpm})$ for $15 \mathrm{~min}$ at room temperature. The tubes were then centrifuged for $15 \mathrm{~min}$ at $2000 \mathrm{rpm}$ in a Beckman TJ-6 centrifuge $\left(\approx 900 g_{\mathrm{n}}\right)$. The upper (aqueous) phase was poured into a clean 50-mL polypropylene tube through two layers of cheesecloth. The interphase and organic phases were usually solid enough to permit the top aqueous phase to be poured off. Occasionally, especially with samples prepared from less leaf tissue than normal, the interface was unstable and the top phase was removed with a pipette.

An equal volume of ice-cold isopropanol was added to each tube of aqueous supernatant, followed by gentle mixing, by inversion, to precipitate the DNA. The precipitation was allowed to proceed for $1 \mathrm{~h}$ at room temperature or overnight at $-20^{\circ} \mathrm{C}$. If the DNA precipitated immediately, it was 'hooked out' after 1 $h$; longer precipitation times may increase the precipitation of unwanted material. The DNA was 'hooked out' with a Pasteur pipette with its tip bent into a ' $U$ '. The mass of DNA was pressed against the inner side of a beaker and rinsed well with a stream of $70 \%$ ethanol from a wash bottle. The DNA, still on the tip of the Pasteur pipette, was then blotted dry on a clean paper tissue (Kimwipes, Kimberly-Clark, Roswell, Ga.), and transferred to a sterile 1.5$\mathrm{mL}$ microfuge tube. The DNA was allowed to air-dry in open tubes to remove the last traces of ethanol. This takes $\approx 15-30 \mathrm{~min}$ at room temperature. If the DNA is dried too thoroughly, it will be very difficult to resuspend in the following step.

The DNA precipitate was dissolved in 650 $750 \mu \mathrm{L}$ of Tris.EDTA (TE) buffer (Sambrook et al., 1989) by incubation in a $65^{\circ} \mathrm{C}$ water bath for $1 \mathrm{~h}$ with occasional gentle inverting and shaking by hand. The tubes were centrifuged in a microfuge at $\approx 12,000 \mathrm{~g}_{\mathrm{n}}$ for $10 \mathrm{~min}$ to pellet anything that did not dissolve, and the supernatant was transferred to another sterile microfuge tube. The remaining pellet may occupy half of the volume of the microfuge tube and consists of very viscous DNA. An additional $500 \mu \mathrm{L}$ of TE was added to the pellet, and the incubation at $65^{\circ} \mathrm{C}$ for $1 \mathrm{~h}$ and 
the centrifugation were repeated. This resuspension of the pellet solubilized a portion of the remaining DNA precipitate and increased the yield of DNA by $100 \%$. The resuspension could be repeated one to two more times before degradation of the DNA became evident upon agarose gel electrophoretic analysis of the unrestricted DNA (Fig. 1).

The quality and concentration of the DNA were checked by running aliquots of undigested and restriction endonuclease digested DNA on a $1 \%$ agarose gel with concentration standards, stained with ethidium bromide. If RNA appeared to be a problem, it was removed by adding DNase-free RNase. If the DNA needed to be concentrated, the supernatant was removed from the microfuge tube and placed in a 15-mL Falcon tube (LPS, Rochester, N.Y.) and precipitated by the addition of $1 /$ 10 volume of $3 \mathrm{~m}$ sodium acetate ( $\mathrm{pH} 5.5$ ) and two volumes (the volume of sodium acetate was included in this calculation) of $95 \%$ ethanol $\left(-20^{\circ} \mathrm{C}\right)$. The contents were mixed by inverting the tube. The precipitation was at $-20{ }^{\circ} \mathrm{C}$ for $1 \mathrm{~h}$ to overnight. The pellet was 'hooked out', rinsed with $70 \%$ ethanol, blotted dry, and finally air-dried, as above. The DNA was resuspended in TE (1/4 of the original volume of supernatant), and heated in a $65^{\circ} \mathrm{C}$ water bath for 30-45 min, with occasional inversion and gentle mixing. The samples were centrifuged in a microfuge for $10 \mathrm{~min}$ at $\approx 12,000 g_{\mathrm{n}}$. The supernatant was transferred to another sterile microfuge tube. The DNA quality and quantity was checked by electrophoresis through a $1 \%$ agarose gel and staining by ethidium bromide.

\section{Results and Discussion}

The protocol described produced pepper genomic DNA of adequate quality and in adequate amounts for restriction digests, Southern analyses, and PCR amplification. Yield of nondegraded DNA was increased significantly by repeated solubilization (up to four times) of the 'hooked-out' precipitated DNA (Fig. 1). The quality of the genomic DNA isolated from six pepper genotypes using this procedure (four varieties of $C$. annuum, plus one each of $C$. frutescens and C. chinense) is routinely satisfactory for analyses used in molecular biology (Fig. 2). Five restriction endonucleases completely digested the DNA, and the resulting Southern gel blot hybridization data were clearly reproducible and informative. DNA from the same six pepper genotypes was also successfully analyzed using primers to detect randomly amplified polymorphic DNA (RAPD) (Fig. 3) (Williams et al., 1990).

Earlier protocols for the preparation of pepper genomic DNA may have been confounded by large amounts of materials presumed to be secondary compounds, carbohydrates, or both. This protocol circumvents these problems. Pepper genomic DNA prepared as detailed here has been digested successfully with over 20 restriction endonucleases. This pepper DNA has been used successfully in Southern hybridizations (Fig. 2)

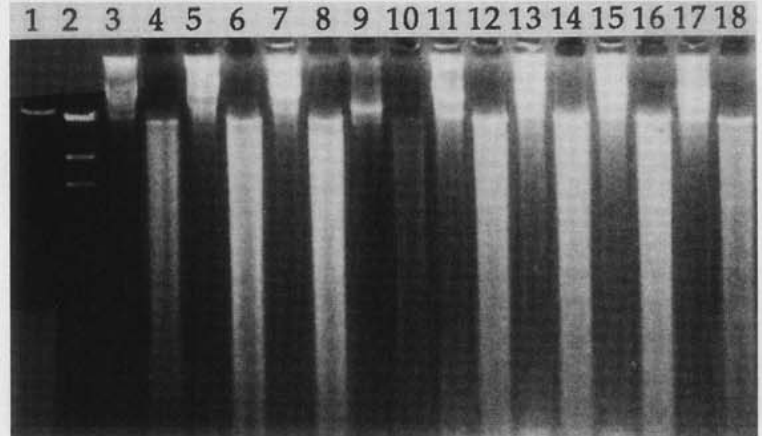

Fig. 1. Repeated solubilization of precipitated pepper genomic DNA increases yield of nondegraded DNA. DNA was subjected to electrophoresis through a $1 \%$ agarose gel and then visualized by ethidium bromide staining. Lanes 1 and 2, lambda DNA; Lane 1, $250 \mathrm{ng}$ undigested; Lane 2, $500 \mathrm{ng}$ HindIII digested. Lanes 3-18, pepper genomic DNA from two $\mathrm{F}_{2}$ plants from $C$. annuum $\times C$. chinense; Lanes 3-10, plant 1; Lanes 11-18, plant 2. Odd-numbered lanes are undigested DNA; even-numbered lanes contain Eco RI-digested DNA. Lanes 3, 4 and 11, 12, first solubilization. Lanes 5, 6 and 13, 14, second solubilization. Lanes 7, 8 and 15,16 , third solubilization. Lanes 9,10 and 17,18 , fourth solubilization.

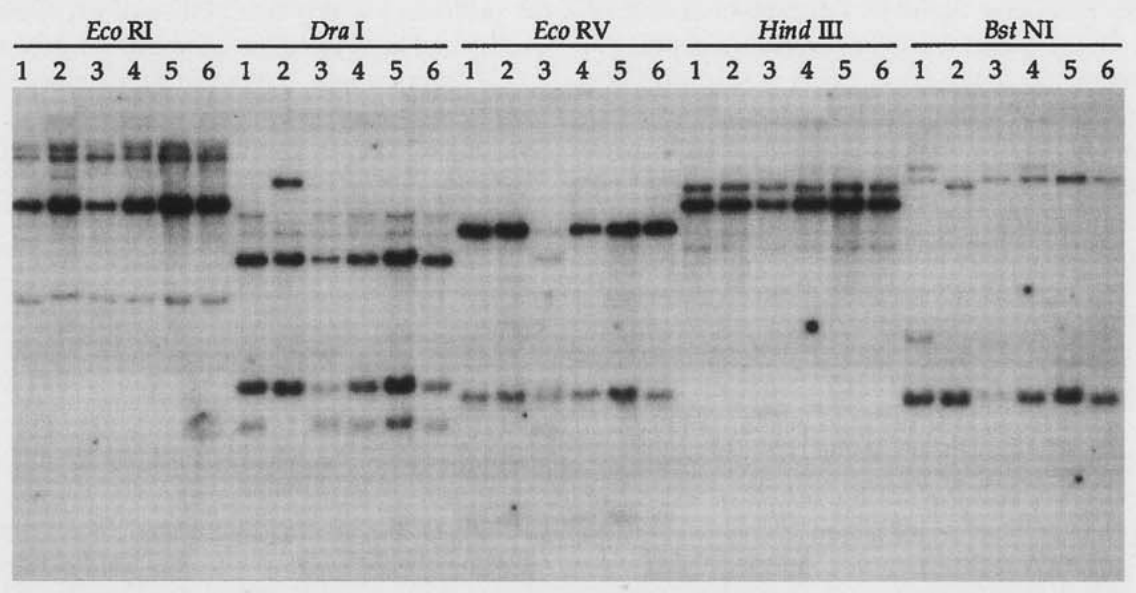

Fig. 2. Autoradiogram of a Southern gel blot hybridized with tomato cDNA clone CT141 demonstrates that pepper genomic DNA from six genotypes is digested completely and reproducibly by a variety of restriction endonucleases. Lanes 1, C. annuum 'Nu Mex R Naky'. Lanes 2, C. chinense PI 159234. Lanes 3, C. frutescens BG2814-6. Lanes 4, C. annuum 'Jupiter'. Lanes 5, C. annuum 'Perennial'. Lanes 6, C. annuum 'Criollo de Morelos'.

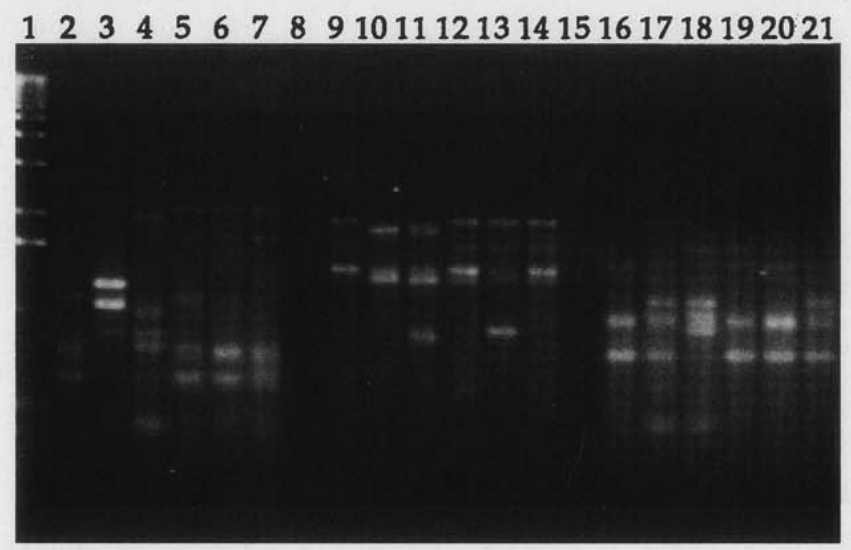

Fig. 3. Pepper genomic DNA isolated from various genotypes is successfully amplified with various RAPD primers. Lane 1, 1 kb DNA ladder (Gibco BRL, Gaithersburg, Md.). Lanes 2-7, RAPD primer 325; Lanes 9-13, primer 361; Lanes 16-21, primer 364. Lanes 2, 9, 16, C. annuum 'Nu Mex R Naky'. Lanes $3,10,17$, C. chinense PI 159234. Lanes 4, 11, 18, C. frutescens BG2814-6. Lanes 5, 12, 19, C. annuum 'Jupiter'. Lanes 6, 13, 20, C. annuum 'Perennial'. Lanes 7, 14, 21, C. annuum 'Criollos de Morelos'. Lanes 8 and 15 , blank. 
(Sambrooket al., 1989), RAPDs (Fig. 3) (Williams et al., 1990), genomic library construction (Prince, 1991; Prince et al., 1995), total genomic DNA labeling by the random hexamer procedure of Feinberg and Vogelstein (1983)

(J.P. Prince, unpublished), and production of PCR products for cloning (E.R. Radwanski, unpublished).

\section{Literature Cited}

Feinberg, A.P. and B. Vogelstein. 1983. A technique for radiolabeling DNA restriction endonuclease fragments to high specific activity. Anal. Biochem. 132:6-13.
McCouch, S., G. Kochert, Z.H. Yu, Z.Y. Wang, G.S. Khush, W.R. Coffman, and S.D. Tanksley. 1988. Molecular mapping of rice chromosomes. Theor. Appl. Genet. 76:815-829.

Prince, J.P. 1991. Organization and evolution of the genome of Capsicum. PhD Diss., Cornell Univ.

Prince, J.P., V.K. Lackney, C. Angeles, J.R. Blauth, and M.M. Kyle. 1995. A survey of DNA polymorphism within the genus Capsicum and the fingerprinting of pepper cultivars. Genome 38:224-231.

Prince, J.P., F. Loaiza-Figueroa, and S.D. Tanksley. 1992. Restriction fragment length polymorphism and genetic distance among Mexican accessions of Capsicum. Genome 35:726-732.

Sambrook, J.,E.F. Fritsch, and T.M. Maniatis (eds.)
1989. Molecular cloning: A laboratory manual. 2nd ed. CSH Laboratory Press, Cold Spring Harbor, N.Y.

Tai, T.H. and S.D. Tanksley. 1990. A rapid and inexpensive method for isolation of total DNA from dehydrated plant tissue. Plant Mol. Biol. Rptr. 8:297-303.

Tanksley, S.D., R. Bernatzky, N.L. Lapitan, and J.P. Prince. 1988. Conservation of gene repertoire but not gene order in pepper and tomato. Proc. Natl. Acad. Sci. USA 85:6419-6423.

Williams, J.G.K., A.R. Kubelik, K.J. Livak, J.A Rafalski, and S.V. Tingey. 1990. DNA polymorphisms amplified by arbitrary primers are useful as genetic markers. Nucl. Acids Res. 18:6531-6535. 